\title{
Klimamodeller og vanddamp
}

Af Peter L. Langen, Center for Is og Klima Niels Bohr Institutet, Københavns Universitet

Ole Humlum kritiserer i GeologiskNyt 2/2008 moderne klimamodeller for deres behandling af vanddamp og hele den hydrologiske cycklus. Kritikken virker noget forfejlet, idet den ser ud til at bygge på en række misforståelser. Jeg giver her en mere præcis beskrivelse af emnet.

I temanummeret om klima bragte GeologiskNyt (nr. 2, apr. 2008) en artikel af Ole Humlum $(\mathrm{OH})$, hvori forfatteren giver en kritisk opsummering af beviser og modbeviser for $\mathrm{CO}_{2}$-drevet global opvarmning. Det efterfølgende nummer (nr. 3, juni 2008) rummer to kommentarer til artiklen: I den ene påpeger Hans Jørgen Henriksen og Klaus Hinsby, at $\mathrm{OH}$ har overset, at selvom temperaturen ser ud til at ændre sig før $\mathrm{CO}_{2} \mathrm{i}$ istidssvingninger, sker ændringerne sandsynligvis som følge af gensidigt forstærkende feedbacks. I forlængelse deraf nævner Philipp von Hessberg i den anden kommentar, at uden disse feedbacks mellem $\mathrm{CO}_{2}$ og klima, ville Jordens klimafølsomhed være så relativt lille, at de små forandringer i Jordens bane omkring solen ikke kunne drive de store istidssvingninger.

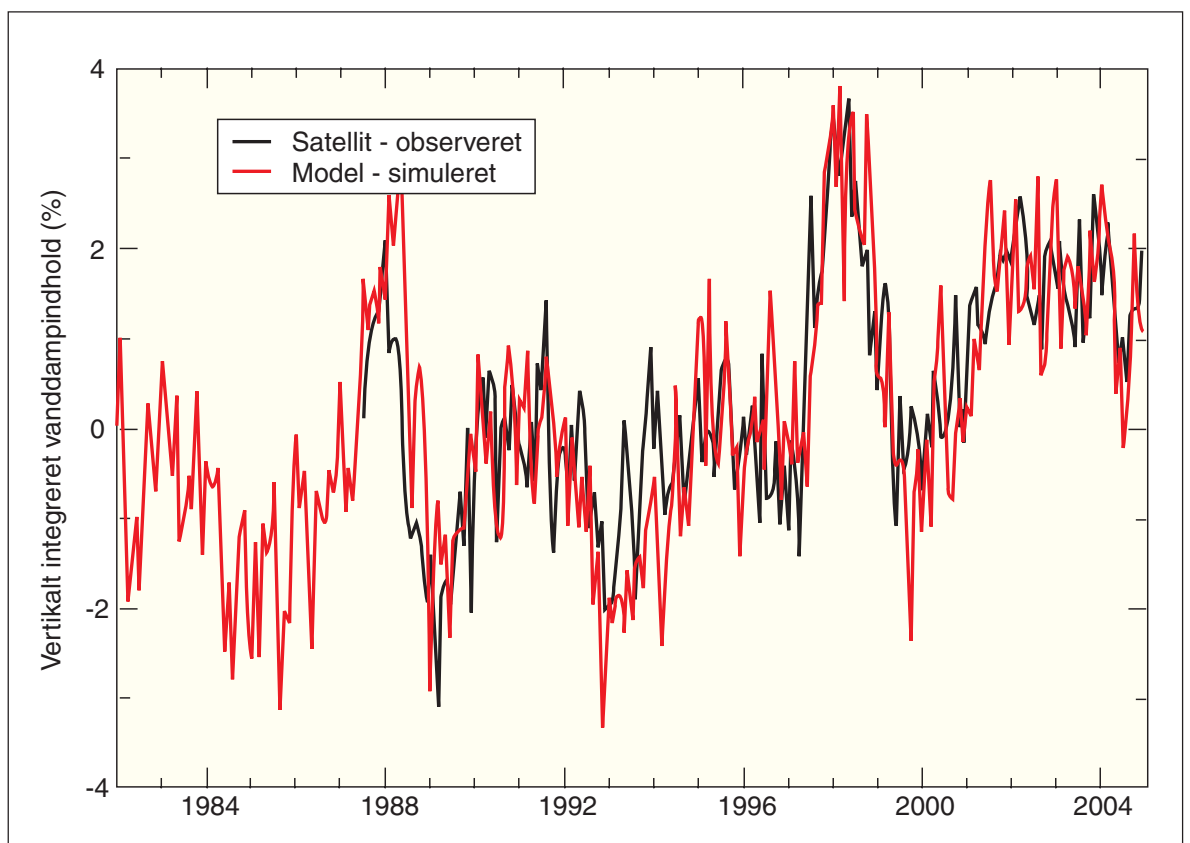

Figur 9.17 (modificeret af UVH) fra IPCC AR4, Climate Change 2007: The Physical Science Basis. Globalt midlede (kun over oceanpunkter) anomalier i forhold til 1987-2000 af vertikalt integreret vanddamp fra simuleringer med den atmosfcriske GCM GFDL AM2-LM2 drevet med observerede havtemperaturer (rød kurve), og satellitobservationer fra SSM/I (sort kurve).

Der er dog stadig særlig en misforståelse, som desværre ser ud til at florere, og den gælder måden, hvorpå moderne klimamodeller håndterer vanddamp. $\mathrm{OH}$ skriver bl.a., at "klimamodeller behandler vanddamp stedmoderligt, som en faktor der passivt styres af ændringer af $\mathrm{CO}_{2}$ ”, og at "Disse vigtige faktorer [vanddamp og skyer] er bare med [i klimamodellerne] som passive følgevirkninger (parameteriseringer) til $\mathrm{CO}_{2}$-ændringer uden selvstændig modellering baseret på fysisk-kemiske lovmæssigheder.” Disse udsagn er direkte forkerte og antyder, at $\mathrm{OH}$ baserer sin kritik af klimamodeller på mangelfuld indsigt.

\section{Vanddamp en selvstændig variabel}

I klimamodelleringens spæde ungdom for ca. 40 år siden var det ikke ualmindeligt, at vanddampmængden i en grid-celle (altså en længdegrads-, breddegrads- og højdekoordinat) var specificeret ud fra observationer eller givet ud fra grid-cellens temperatur under en antagelse om konstant relativ fugtighed. Allerede for mere end 30 år siden var vanddamp dog blevet en selvstændig variabel i modellerne. Mig bekendt har man aldrig i tre-dimensionelle klimamodeller beregnet en grid-celles vanddampindhold direkte ud fra $\mathrm{CO}_{2}$-koncentrationen.

I moderne modeller ( $\mathrm{fx}$ dem der ligger til grund for IPCC-rapporterne) er man nået meget videre, og alle de hydrologiske processer, som $\mathrm{OH}$ nævner (og antyder ikke skulle være medtaget i modellerne), modelleres eksplicit: Fordampning fra en jord- eller havoverflade beregnes ud fra overfladens beskaffenhed (fx fugtighed og ruhed) samt meteorologiske faktorer som overfladens temperatur, den ovenliggende lufts temperatur og fugtighed, stabiliteten af den nederste del af atmosfæren, vindhastighed og meget andet. Der udrenges så, hvor meget energi der er gået til fordampningsprocessen (fordampningsvarme), og overfladen køles tilsvarende. Nu hvor vanddampen er kommet op i atmosfæren, holdes der styr på, hvor den blæses hen med henholdsvis horisontale og vertikale vinde. Det beregnes også, hvad dens effekt er på atmosfærens strålingsbudget i forhold til absorption, refleksion og spredning af solindstråling og absorp- 
tion og gen-emmission af infrarød stråling (over en serie af spektrale bånd). Vertikale hastigheder, tryk, temperatur, fugtighed og en lang række andre dynamiske felter i modellen bestemmer, hvor og hvornår vanddampen kondenserer og danner skyer. Den frigivne energi ved kondensation bruges til at opvarme luften i grid-cellen. Typen af skyer (vanddråber/iskrystaller, form- og størrelsesfordeling af dråberne) bestemmes også dynamisk og har indflydelse på skyens strålingsmæssige egenskaber. Nedbør, nedbørstype (regn/sne) og genfordampning af faldende nedbør beregnes også ud fra de dynamiske meteorologiske parametre. Mange andre processer har indflydese på modellernes vanddampsfelt, og undervejs i hele kredsløbet sikres det, at mængden af både vand og energi er bevaret.
Denne måde, hvorpå langt størstedelen af de hydrologiske processer, vi kender til og forstår, er modelleret eksplicit, resulterer i vanddampsfelter, hvis tidslige og rumlige variationer stemmer godt overens med observationerne.

Figuren (fra IPCC) viser et eksempel med den amerikanske GFDL-model. Den sorte kurve giver globalt midlet, vertikalt integreret vanddampindhold målt med satellit, mens den røde kurve er den samme størrelse, men taget direkte fra en klimamodelkørsel. Overensstemmelsen er overbevisende. Det skal her nævnes, at man i atmosfæremodellen har anvendt observerede havoverfladetemperaturer som nedre grænsebetingelse. Modellen simulerer så selvstændigt vinde, temperaturer, vanddamp osv. Figuren siger ikke, at modellen perfekt kan gengive den tidslige udvikling af klimaet. Den viser derimod, at hvis man alene giver den information om den observerede tidslige og rumlige udvikling af havtemperaturerne, så udregner modellen en tidslig udvikling af atmosfærens tilstand, der i vanddampsfeltet svarer meget nøje til observationerne. Det ser altså ikke ud til at være i modellens håndtering af vanddamp, de største problemer ligger.

I min egen forskning bruger jeg en sådan model til at spore vanddamp i atmosfæren, fra det fordamper, til det falder som regn og sne. På denne måde kan jeg bestemme kildeområderne for nedbøren ved fx borestederne for de grønlandske iskerner. Sådanne studier ville ikke kunne foretages, hvis klimamodeller kun behandlede "vanddamp stedmoderligt som en faktor der passivt styres af ændringer af $\mathrm{CO}_{2}$ ”.

\section{Kort nyt}

\section{Gletscherafsmeltning på Grønland}

Jørgen Peder Steffensen, iskerneforsker fra Københavns Universitet, udtrykker bekymring for hastigheden af afsmeltningen af de grønlandske gletschere. Ifølge Jørgen Peder Steffensen nåede de grønlandske gletschere formentlig deres maksimale udstrækning i 1997. Under vikingetiden for 1.000 år siden lå de grønlandske gletschere ca. 20-30 km længere tilbage end i dag. At gletschere bevæger sig, er helt normalt, men problemet de senere år er, at afsmeltningen af gletscherne går for stærkt, siger den danske iskerneforsker.

Jørgen Peder Steffensen er heller ikke i tvivl om, at den globale opvarmning vil få betydning for afsmeltningshastigheden af isen på Grønland. Der vil måske afsmelte 20-30 \% af isen på Grønland i løbet af de næste 1.000 år, hvilket vil afstedkomme en betydelig stigning af vandmængderne i verdenshavene. Ret meget hurtigere vil det ikke gå ifølge Jørgen Peder Steffensen, for sidste gang, der var istid på den nordlige halvkugle, tog det 3.000 år for isen at smelte.

I 2007 forsvandt 240 kubikkilometer is fra indlandsisen i Grønland. Det svarer til astronomiske 240.000 milliarder liter vand eller ca. 580 gange Danmarks samlede årlige vandforbrug. Men isen på Grønland er udregnet til at indeholde næsten tre milliarder kubikkilometer is og vil derfor næppe forsvinde de første mange hundrede år trods den globale opvarmning. 